\title{
Produksi Iklan Pariwisata Audio Visual Belitung Timur
}

\author{
Altobeli Lobodally \\ Ilmu Komunikasi, Fakultas Industri Kreatif Kalbis Institute \\ Jalan Pulo Mas Selatan Kav 22 \\ Email: altobeli.lobodally@kalbis.ac.id
}

\begin{abstract}
Tourism nowadays has become lifestyle for some people. Tourism objects, both in remote area or in a big city, now become the tourist destination for the activator. Finally, there are competitions between tourist objects to seduce market. Advertising is the main key in order to seducing the consumer of the tourist objects. This training is giving to Belitung Timur Tourist Office and also the tourist area manager. This training is giving the basic skills to packaging tourism advertising. Especially, the audio visual tourism advertising. So, from this training the participant will make a tourism advertising audio visual project.
\end{abstract}

Keywords: advertising, audio visual, community service, tourism

\begin{abstract}
Abstrak: Pariwisata dewasa ini telah menjadi gaya hidup tersendiri bagi sebagian besar kalangan. Objek-objek wisata baik di daerah terpencil maupun di kota besar, kini menjadi tujuan bagi para penggiatnya. Objek-objek wisata tersebut akhirnya bersaing dalam merebut pasar. Iklan merupakan kunci penting dalam merayu konsumen agar terpikat dengan pesona objek wisata tersebut. Kegiatan pelatihan ini diberikan bagi Dinas Pariwisata Belitung Timur dan juga para pengelola daerah wisata. Pelatihan ini memberikan kemampuan dasar dalam mengemas sebuah produksi iklan pariwisata. Produksi iklan pariwisata yang diberikan adalah iklan pariwisata audio visual. Sehingga akan menyajikan objek wisata Belitung Timur agar dapat merayu pasar konsumen.
\end{abstract}

Kata kunci: audio visual, iklan, layanan masyarakat, pariwisata

\section{PENDAHULUAN}

Periwisata adalah salah satu potensi pendapatan nasional maupun daerah selain industri dan migas. Indonesia dianugrahi oleh kekayaan alam dan budaya. Salah satunya adalah Propinsi Bangka Belitung. Wilayah Propinsi Bangka Belitung adalah kepulauan yaitu Pulau Bangka dan Pulau Belitung. Pulau Belitung terdapat dua Kabupaten yaitu Kabupaten Belitung Barat dan Kabupaten Belitung Timur. Nama Belitung menjadi terkenal setelah novel karya Andrea Hirata diangkat ke layar lebar dalam film berjudul "Laskar Pelangi". Film yang bercerita tentang lima orang anak yang tinggal di daerah pertambangan timah memiliki mimpi untuk keliling dunia. Dalam film tersebut menampilkan kekayaan alam di Belitung khususnya pantai yang indah dengan batu granit besar. Wisatawan lokal dan Internasional pun berdatangan ke Belitung, namun hanya ke Belitung Barat, sehingga wisatanya pun berkembang. Sementara Kabupaten Belitung Timur yang jaraknya sekitar 60,9 km dengan waktu tempuh satu setengah jam melalui darat dari Belitung Barat, wisata dan budayanya belum banyak tergali. Wisatawan hanya berkunjung ke Kecamatan Gantong, karena disana terdapat replika sekolah laskar pelangi dan Museum Kata. Sementara tempat wisata dan budaya yang ada di Belitung Timur tidak banyak tergali.

Untuk itu perlu sebuah medium untuk memperkenalkan potensi wisata yang dimiliki oleh Belitung Timur. Salah satunya adalah dengan menggunakan iklan audio visual. Pelatihan iklan audio visual dipilih untuk memberikan gambaran langsung pengalaman melakukan kegiatan wisata. Hal ini mengingat karakteristik audio visual yang mampu menyajikan secara langsung objek yang dapat dilihat maupun didengar. Sehingga melalui pembuatan iklan audio visual pariwisata Belitung Timur ini akan tergambar dengan jelas setiap objek wisata di Belitung Timur serta dapat menarik minat bagi para wisatawan untuk mengunjungi tempat tempat tersebut.

\section{METODE PELAKSANAAN}

\section{A. Iklan Audio Visual}

Iklan merupakan bentuk promosi yang dapat digunakan untuk meyakinkan konsumen mengenai produk yang dipasarkan. Iklan (advertising) merupakan setiap bentuk komunikasi non personal 
mengenai suatu organisasi, produk, jasa, atau ide yang dibayar oleh sponsor (Morissan, 2010: 17).

Jaiz (2014:1) mengungkapkan bahwa: "tujuan periklanan mengandung misi komunikasi". Media periklanan terdiri dari media lini atas (above the line) dan media lini bawah (below the line).

Secara gamblang Jaiz (2014: 1) menjelaskan bahwa media lini atas (above the line), adalah jenis iklan yang pemasangannya mengharuskan adanya pembayaran/ komisi kepada biro iklan. Komunikasi dari media lini atas ini adalah "sewa media yang sifatnya massal". Adapun tujuan dari pemasangan iklan menggunakan media lini atas ini adalah untuk membangun image dari iklan tersebut. Salah satu contoh dari media lini atas adalah iklan audio visual.

Media iklan audio visual merupakan salah satu bentuk promosi untuk memperkenalkan dan memberikan pengetahuan serta ajakan langsung kepada calon konsumen untuk membeli produk. Untuk memperkenalkan sebuah produk melalui iklan audio visual, content yang ada di dalamnya harus dibuat semenarik mungkin agar calon konsumen yang sudah terpengaruh akan melakukan pembelian produk yang diiklankan. Artinya konsep untuk membuat iklan audio visual haruslah kuat. Sehingga dapat menjadi alat untuk membujuk konsumen.

Adapun kelebihan iklan audio visual ini adalah dapat membangun atau membentuk presepsi konsumen dengan kuat dan menjangkau khalayak secara luas. Artinya dengan adanya iklan audio visual ini diharapkan dapat memperkuat pesan promosi agar lebih berdampak pada target audience. Kemenarikan sebuah iklan audio visual ini dapat dilihat dari beberapa unsur di dalamnya, seperti audio, gambar dan teks. Pesan yang baik akan dirancang oleh seorang komunikator untuk memutuskan apa yang harusdikatakan (isi pesan), dan cara mengatakannya (struktur dan format pesan), termasuk iklan audio visual.

Dalam pelatihan ini, akan diberikan sebuah pelatihan dalam membentuk konsep iklan audio visual yang menarik. Peserta pelatihan akan diajak untuk menggali potensi wisata Belitung Timur dan mengemasnya.

\section{B. Pelaksanaan Pengabdian Kepada Masyarakat}

Pelaksanaan kegiatan pengabdian kepada masyarakat ini diawali dengan penjajakan kebutuhan yang diperlukan oleh mitra pengabdian kepada masyarakat. Dalam kegiatan penjajakan tersebut, penulis menemukan bahwa Belitung sendiri memang sudah dikenal masyarakat umumnya. Nama Belitung menjadi popular setelah Film Laskar Pelangi mengangkat mimpi dan kisah sukses anak-anak di Belitung.

Melalui film tersebut, masyarakat tidak hanya mengenal dinamika pendidikan di Belitung, akan tetapi film tersebut juga mengenalkan keindahan alam Belitung. Film tersebut menunjukkan keindahan alam Belitung yang dapat menjadi aset bagi dunia Pariwisata. Film ini akhirnya juga tentu mengangkat pariwisata Belitung, namun umumnya wisatawan hanya mengunjungi Belitung Barat. Belitung Timur belum dikunjungi wisatawan.

Belitung Timur atau Kabupaten Belitung Timur jaraknya sekitar 60,9 km dengan waktu tempuh 1,5 jam lewat darat dari Belitung Barat. Melalui kegiatan pengabdian kepada masyarakat ini, penulis memberikan pengetahuan bagi dinas pariwisata Belitung Timur mengenai konsep promosi secara audio visual.

Kegiatan Pengabdian Kepada Masyarakat ini dilakukan pada tanggal 1 Juni 2020. Karena pelaksanaan kegiatan ini dilakukan pada saat pandemik, maka pemberian materi dilakukan dengan menggunakan aplikasi zoom. Pemberi materi berada di Jakarta, sementara para peserta berada di Belitung Timur. Seperti yang ditunjukkan dalam Gambar 1.

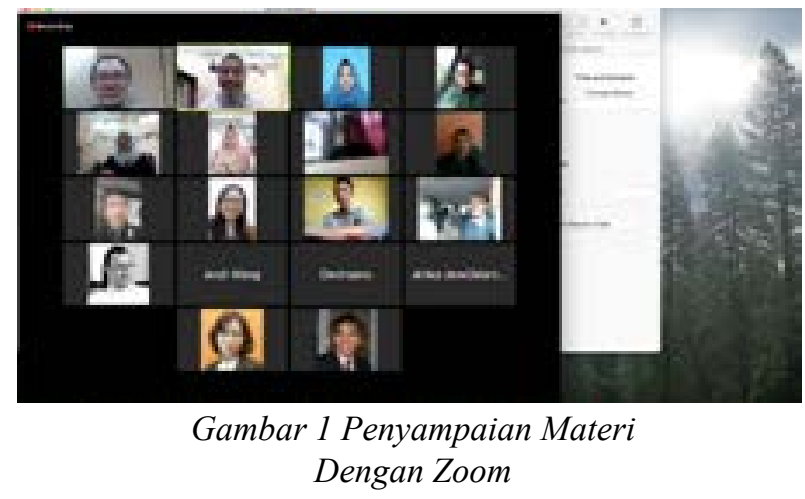

Pemberi materi dalam kegiatan Pengabdian Kepada Masyarakat ini adalah dosen tetap Kalbis Institute, Altobeli Lobodally, S.Sos, M.IKom. Pemateri mengawali materi dengan bertanya kepada masing-masing peserta mengenai tempat-tempat menarik di Belitung Timur yang dapat diangkat sebagai daya tarik pariwisata. Pemateri menanyakan kepada masing-masing peserta, mengenai tempat dan apa saja yang dapat dilakukan turis di tempat tersebut. Pemateri berupaya menggali product knowledge dari masing-masing tempat wisata yang menjadi kekuatan bagi Belitung Timur. Hal tersebut dapat dilihat dalam Gambar 2 berikut ini: 


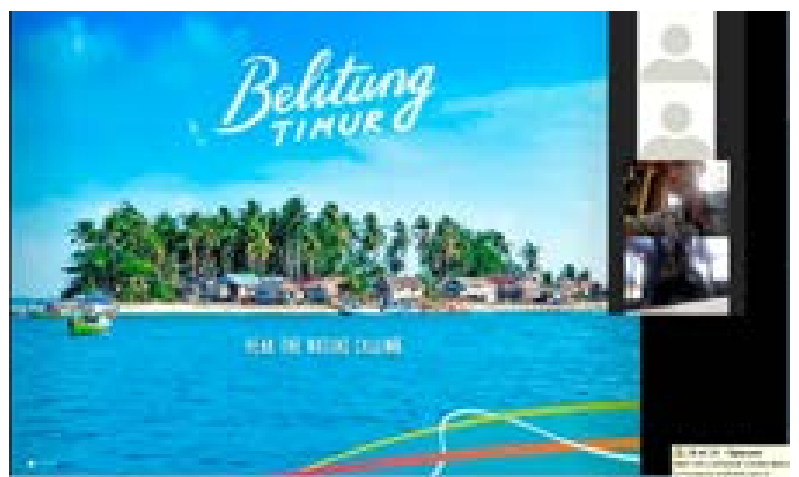

Gambar 2 Product Knowledge

Setelah memahami hal-hal yang menjadi kekuatan dari tempat wisata di Belitung Timur kemudian pemberi materi, meminta para peserta untuk mencari pusat ide yang akan menjadi titik awal konsep produksi audio visual. Setelah pusat ide ditemukan, masing-masing peserta kemudian diberi penjelasan mengenai ide cerita dan gambaran menjabarkannya. Tahapan ini dapat disaksikan dalam Gambar 3.

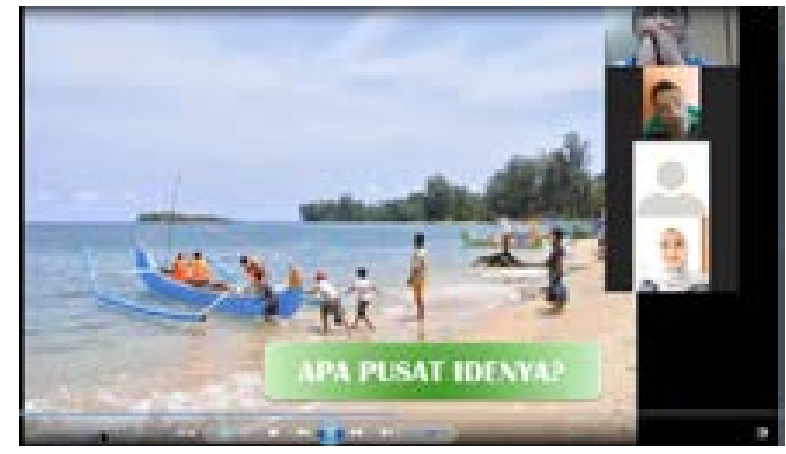

Gambar 3 Pusat Ide

Tahapan berikutnya, adalah pemberi materi memberikan kesempatan bagi para peserta untuk membuat ide cerita untuk iklan audio visual yang akan dibuatnya. Selama peserta membuat ide untuk iklan audio visualnya, pemberi materi juga memberikan contoh mengenai iklan audio visual yang baik dari sisi komposisi gambar maupun penggunaan modelnya.

Kegiatan pengabdian kepada masyarakat untuk Dinas Pariwisata berlangsung selama lebih kurang dua jam. Selama pemberian materi, masing-

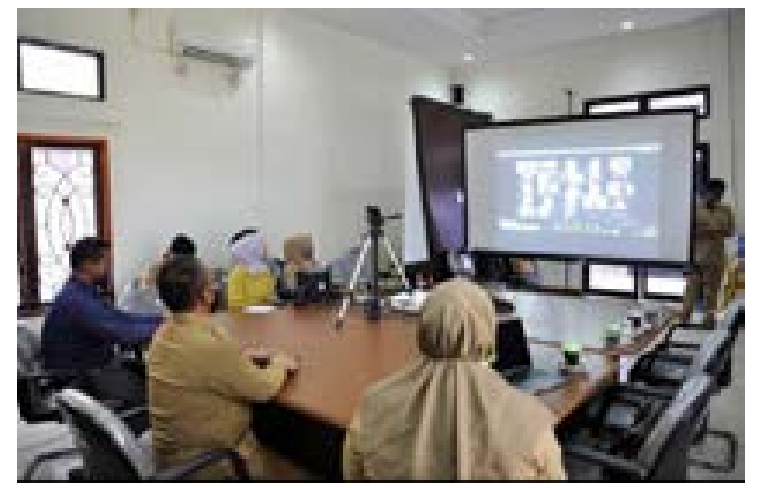

Gambar 4 Antusiasme Peserta masing peserta dengan antusias mengikuti kegiatan pengabdian kepada masyarakat ini. Hal ini dapat disaksikan dalam Gambar 4.

Kegiatan pengabdian kepada masyarakat kemudian ditutup dengan tanya jawab masingmasing peserta. Pada umumnya peserta menanyakan keterbatasan peralatan yang dimiliki untuk memproduksi iklan audio visual. Namun sesungguhnya telepon selular sudah dapat cukup mampu untuk mengatasinya. Dengan syarat, memang telah memiliki konsep ide yang jelas.

\section{HASIL DAN PEMBAHASAN}

Kegiatan pengabdian kepada masyarakat bagi Dinas Pariwisata Belitung Timur ini memang merupakan sebuah rangkaian kegiatan pengabdian kepada masyarakat. Kalbis Institute khususnya Prodi Ilmu Komunikasi menawarkan beragam tema selama dua bulan untuk meningkatkan Brand Pariwisata Belitung Timur.

Tema-tema yang diberikan antara lain Komunikasi Pemasaran Terpadu, Literasi Digital, Membangun Brand, hingga produksi iklan secara digital. Walaupun sudah dilakukan kegiatan pengabdian kepada masyarakat secara berkala selama dua bulan secara daring, akan tetapi tetap dibutuhkan kegiatan pengabdian kepada masyarakat secara offline.

Kegiatan pengabdian kepada masyarakat secara offline sebaiknya dilakukan, terutama untuk tema-tema yang mengharuskan produksi. Sehingga pemberi materi dapat mendampingi secara langsung proses pembuatan iklan pariwisata tersebut. Namun kondisi pandemik membuat kegiatan tersebut urung dilakukan.

\section{SIMPULAN}

Melalui kegiatan pengabdian kepada masyarakat ini, ada beberapa kemampuan yang dapat dimiliki oleh para peserta: Memahami product knowledge yang menjadi keunggulan tempat wisatanya; Memahami pusat ide yang dapat menjadi ide awal dalam memproduksi iklan audio visual; Mampu menuangkan ide menjadi sebuah konsep produksi iklan audio visual.

\section{DAFTAR RUJUKAN}

Morissan, M.A. (2010). Periklanan: Komunikasi Pemasaran Terpadu. Jakarta: Kencana.

Jaiz, M. (2014). Dasar-Dasar Periklanan Cetakan ke I. Yogyakarta:Graha Ilmu. 